\title{
CHEMICAL COMPOSITION AND AMOUNTS OF MINERAL ELEMENTS IN HONEYBEE-COLLECTED POLLEN IN RELATION
} TO BOTANICAL ORIGIN

\author{
I El-Kazafy Abdou Taha1,2,* \\ 'Department of Arid Land Agriculture, College of Agriculture \\ and Food Sciences, King Faisal University, Al-Hasa, Saudi Arabia \\ 2Department of Economic Entomology, Faculty of Agriculture, Kafrelsheikh \\ University,Kafrelsheikh, Egypt \\ *corresponding author: etaha@kfu.edu.sa \\ Received 17 August 2014; accepted 07 May 2015
}

\begin{abstract}
A bstract
This study was conducted at the apiary of the Agricultural and Veterinary Training and Research Station, King Faisal University, Al-Ahsa, Saudi Arabia. The purpose was to study the relationship between the botanical origin and chemical composition of bee-collected pollen. The amount of mineral elements present in bee-collected pollen was also studied. The composition of pollen loads showed the maximum contents of dry matter, ash, glucose, fructose, magnesium (Mg), phosphorus (P), and manganese (Mn) for the date palm; the maximum contents of protein, calcium (Ca), and zinc ( $\mathrm{Zn}$ ) for alfalfa; the maximum contents of fiber, and copper ( $\mathrm{Cu}$ ) for the sunflower; the maximum contents of the lipids and iron ( $\mathrm{Fe}$ ) for summer squash; and the maximum contents of sodium $(\mathrm{Na})$, and potassium $(\mathrm{K})$ for rape. Calcium was found to be correlated in a significantly $(p<0.01)$ positive way with $\mathrm{K}, \mathrm{Na}, \mathrm{Mg}, \mathrm{P}, \mathrm{Mn}$, and $\mathrm{Zn}$. Copper, though, was correlated in a significantly $(p<0.01)$ negative way with $\mathrm{Ca}, \mathrm{Mg}, \mathrm{P}, \mathrm{Mn}$, and $\mathrm{Zn}$. The high levels of protein, ash, glucose, and fructose, and low lipid content found in bee-pollen from the date palm and from alfalfa, mean that pollen from the date palm and from alfalfa make an excellent food supplement. It was concluded, that the chemical composition of beecollected pollen can be correlated with the plant species from which pollen was collected.
\end{abstract}

Keywords: bee-pollen, botanic origin, chemical composition, minerals.

\section{INTRODUCTION}

The natural diet of the honeybee is pollen and nectar. Pollen is more crucial than nectar for the production of brood because it provides the nutritional requirements for developing bees. Pollen constitutes the main source of protein necessary for bee larvae and young workers (Crailsheim et al., 1992; Serra Bonvehi and Escola Jorda, 1997).

Honeybee-collected pollen has an important value not only for bee nutrition, but also for humans. Honeybee-collected pollen provides a rich source of easily digestible protein (Crailsheim et al., 1992; Campos et al., 1996; Serra Bonvehi and Escola Jorda, 1997; Szczęsna, 2006a; b). In addition to proteins, pollen also contains carbohydrates, fats and minerals (Orzáez Villanueva et al., 2002; Szczęsna et al., 2002; Almeida-Muradian et al., 2005; Human and Nicolson, 2006; Szczęsna, 2006a; 2007; Campos et al., 2008; Carpes et al., 2009; Martins et al., 2011; Morgano et al., 2012). The chemical composition of bee-pollen showed an average of $7.40 \%$ moisture, $20.00 \%$ protein, $6.00 \%$ lipids, and $2.20 \%$ ash (Almeida-Muradian et al., 2005). Different values (4.20, 20.50, 4.90, and 2.90\%, respectively) of Brazilian bee-pollen were found by Carpes et al. (2009).

The chemical composition of bee-pollen is known to vary according to the plant species from which the pollen was collected (Szczęsna et al., 2002; 2006a; Morgano et al., 2012), the geographic origin (Serra Bonvehi and Escola Jorda, 1997; Carpes et al., 2009; Martins et al., 2011; Morgano et al., 2012), the season (Szczęsna et al., 2002; Morgano et al., 2012), and the storage and storage method (Human and Nicolson, 2006; Siuda et al., 2012).

Bee-pollen was involved in formulating supplementary food products because of its nutritional and therapeutic properties (lannuzzi, 1993; Campos et al., 1996; Serra Bonvehi and Escola Jorda, 1997; Pernal and Currie, 2000; Orzáez Villanueva et al., 2002; Kacániová et al., 2012; Morgano et al., 2012). 
Bee-pollen was also used in pollen supplements (lannuzzi, 1993). For the aforementioned purposes, it is very important to select bee-pollen which has a high nutritional value. The present investigation was aimed to classify the bee-pollen from different botanical origins according to their nutritional value, so that high quality pollen may be produced.

\section{MATERIAL AND METHODS}

The study was conducted at the apiary of the Agricultural and Veterinary Training and Research Station, King Faisal University, Al-Ahsa (Saudi Arabia) that lies at latitude $25^{\circ} 25^{\prime} 46^{\prime \prime} \mathrm{N}$ and longitude $49^{\circ} 37^{\prime} 19^{\prime \prime} E$ and an altitude of $121 \mathrm{~m}$ above sea level. Throughout the year, five colonies (each of seven combs) of hybrid Carniolan honeybees in the same strength (brood, stored food, and bee strength) were used for pollen trapping.

Pollen traps with a $25 \%$ efficiency were fitted onto the entrances of the colonies. Twice a week, from January to December in 2013, the pollen loads were collected from the pollen traps. The pollen loads were dried at room temperature in a shady place for one hour to facilitate the separation and referred to its sources, then dried at $30^{\circ} \mathrm{C}$ for $2 \mathrm{~h}$ and weighed. The collected bee-pollen was hand-sorted by color and appearance, and floral origin of each fraction was identified by microscopical examinations. Pollen types were identified according to their shape and size by comparison with pollen reference slides made by the author. The procedure of preparation of reference slides was described by Louveaux et al. (1978). Pollen samples containing mainly monofloral pollen loads from summer squash (Cucurbita pepo Thunb), date palm (Phoenix dactylifera L.), sunflower (Helianthus annuus L.), rape (Brassica napus L.) and alfalfa (Medicago sativa L.) were selected as major sources, and stored at $-21^{\circ} \mathrm{C}$ until analysed. Samples used for determination were collected during February-March for summer squash, date palm, rape and sunflower, and during May for alfalfa, summer squash and sunflower.

The determination of the chemical composition of dried bee-pollen was done as follow: dry matter was determined by drying $2.00 \mathrm{~g}$ of pollen sample at $105^{\circ} \mathrm{C}$ to a constant weight (Serra Bonvehi and Casanova, 1987). A sample of $0.07 \mathrm{~g}$ was used to determine the nitrogen by the micro-Kjeldahl method (AOAC, 1995) using the 5.60 factor for conversion into crude protein (Rabie et al., 1983). In order to compare our findings with those of other studies which used the factor 6.25 for a nitrogen conversion to protein, we recalculated their values using factor
5.60. A sample of $2.00 \mathrm{~g}$ was used for determination of the lipids using a Soxhlet extractor with diethyl ether as the solvent (Folch et al., 1957). The ash determination was made by incinerating $2.00 \mathrm{~g}$ in an oven at $550^{\circ} \mathrm{C}$ until a constant weight was reached (Almeida-Muradian et al., 2005). The crude fiber was quantified by gravimetry from $2.00 \mathrm{~g}$ of crushed pollen, in accordance with the fibers method 991.43 (AOAC, 1995). A sample of $2.00 \mathrm{~g}$ was used to determine the content of fructose and glucose in bee-pollen by the utilization of HPLC technique as described by Szczęsna (2007). Glycemic index (F/G) of bee pollen was calculated. All components were calculated basing on dry matter.

A sample of $1.00 \mathrm{~g}$ was used for determination of mineral content. Wet digestion with nitric acid following the method of Taha et al. (2010), was used to prepare the pollen samples for the determination of the mineral content. A blank experiment was carried out by adding the same amount of nitric acid to one $\mathrm{mL}$ distilled water. An Atomic Absorption GBC AVANTA $\Sigma$ GF 3000 was used for the detection of iron (Fe), manganese (Mn), zinc ( $\mathrm{Zn})$, and copper (Cu). Sodium ( $\mathrm{Na})$, potassium $(\mathrm{K})$, calcium $(\mathrm{Ca})$, magnesium $(\mathrm{Mg})$, and phosphorus $(\mathrm{P})$ concentrations were determined using a flame photometer. The instrument was calibrated by using standard solutions of various metal salts. All determinations were made in triplicate and calculated based on dry matter.

Data were subjected to the one-way analysis of variance (ANOVA). Treatment means were compared using Duncan's Multiple Range Test (Duncan, 1955). The Pearson correlation between minerals was determined using SAS Institute (2003).

\section{RESULTS}

In the semi-arid conditions that cover most parts of Saudi Arabia, the temperatures during summer season often exceed $40^{\circ} \mathrm{C}$. In January the mean temperature is $16^{\circ} \mathrm{C}$ which is adequate for growth and blooming of summer squash and rape. Sunflower is grown and flowered more than once in the year. The yearly amounts of trapped pollen loads were $2.50 \mathrm{~kg} /$ colony. Five species were recorded as major sources and they contributed $94.76 \%$ of the total yearly collected pollen loads. The highest significant $(p<0.01)$ amount of pollen loads was obtained from summer squash, followed by date palm without significant differences between them, while the lowest significant $(p<0.01)$ amount was collected from rape (Tab. 1). 
As shown in Table 2, the percentages of ash, protein, lipid, fiber, fructose and glucose content in bee collected-pollen were variable and depended significantly $(p<0.01)$ on the botanical origin. The chemical composition of bee-pollen showed the highest significant $(p<0.01)$ values of dry matter $(90.84 \%)$, ash (3.88\% DM), fructose (21.30\% DM) and glucose $(17.06 \%$ DM) for date palm, protein (19.45\% DM) for alfalfa, lipids (5.38\% DM) for summer squash, and fibers $(1.70 \%$ DM) for sunflower.
Data listed in Table 3 show that the amount of mineral elements in bee collected-pollen were variable and depended significantly $(p<0.01)$ on the botanical origin. The highest levels of sodium $(\mathrm{Na})$ and potassium (K); calcium (Ca) and zinc (Zn); magnesium (Mg), phosphorus (P), and manganese $(\mathrm{Mn})$; iron (Fe); and copper (Cu) were obtained from the pollen of rape; alfalfa; date palm; summer squash; and sunflower, respectively.

Table 1.

Yearly average amount of pollen loads (g/colony) collected from the major pollen sources in the Al-Ahsa region in 2013

\begin{tabular}{|c|c|c|c|}
\hline \multicolumn{2}{|c|}{ Botanical origins } & \multirow{2}{*}{ Blooming period } & \multirow{2}{*}{$\begin{array}{l}\text { Amount (g) of } \\
\text { trapped pollen }\end{array}$} \\
\hline Common name & Scientific name & & \\
\hline Summer squash & Cucurbita pepo Thunb & January-May, September-October & $528 \pm 17.05^{a}$ \\
\hline Date palm & Phoenix dactylifera L. & February-March & $515 \pm 10.40^{a}$ \\
\hline Sunflower & Helianthus annuus L. & February-October & $454 \pm 15.12^{b}$ \\
\hline Alfalfa & Medicago sativa L. & May-June & $446 \pm 10.90^{b}$ \\
\hline Rape & Brassica napus L. & January-March & $426 \pm 11.40^{c}$ \\
\hline Minor sources & - & January-December & $131 \pm 18.40^{d}$ \\
\hline The total & - & - & 2500 \\
\hline
\end{tabular}

Values are the mean \pm S.D. The means of each column followed by a different letter are significantly different at the 0.01 level.

Chemical composition (\% DM) of bee-pollen in relation to botanical origin

\begin{tabular}{ccccccc}
\hline \multirow{2}{*}{ Component } & \multicolumn{5}{c}{ Botanical origins } & \multirow{2}{*}{ Significance } \\
\cline { 2 - 6 } & Sunflower & $\begin{array}{c}\text { Summer } \\
\text { squash }\end{array}$ & Date palm & Rape & Alfalfa & \\
\hline Dry matter & $90.81 \pm 0.30 \mathrm{a}$ & $89.50 \pm 0.50 \mathrm{c}$ & $90.84 \pm 0.06 \mathrm{a}$ & $90.27 \pm 0.23 \mathrm{~b}$ & $90.16 \pm 0.16 \mathrm{~b}$ & ${ }^{\star *}$ \\
\hline Protein & $14.71 \pm 0.10 \mathrm{e}$ & $15.82 \pm 0.15 \mathrm{~d}$ & $19.00 \pm 0.11 \mathrm{~b}$ & $18.14 \pm 0.05 \mathrm{c}$ & $19.45 \pm 0.05 \mathrm{a}$ & ${ }^{\star *}$ \\
\hline Lipids & $4.45 \pm 0.05 \mathrm{~b}$ & $5.38 \pm 0.05 \mathrm{a}$ & $1.82 \pm 0.02 \mathrm{e}$ & $3.92 \pm 0.04 \mathrm{c}$ & $2.89 \pm 0.10 \mathrm{~d}$ & ${ }^{\star *}$ \\
\hline Ash & $2.01 \pm 0.03 \mathrm{~d}$ & $1.88 \pm 0.10 \mathrm{e}$ & $3.88 \pm 0.03 \mathrm{a}$ & $3.32 \pm 0.02 \mathrm{c}$ & $3.74 \pm 0.01 \mathrm{~b}$ & ${ }^{\star *}$ \\
\hline Fibers & $1.70 \pm 0.02 \mathrm{a}$ & $0.97 \pm 0.01 \mathrm{~b}$ & $0.15 \pm 0.01 \mathrm{e}$ & $0.46 \pm 0.01 \mathrm{~d}$ & $0.78 \pm 0.01 \mathrm{c}$ & ${ }^{\star *}$ \\
\hline Fructose & $17.23 \pm 0.08 \mathrm{c}$ & $17.80 \pm 0.09 \mathrm{~b}$ & $21.30 \pm 0.12 \mathrm{a}$ & $17.13 \pm 0.05 \mathrm{c}$ & $19.51 \pm 0.06 \mathrm{a}$ & ${ }^{\star *}$ \\
\hline Glucose & $15.44 \pm 0.11 \mathrm{c}$ & $16.66 \pm 0.09 \mathrm{a}$ & $17.06 \pm 0.07 \mathrm{a}$ & $16.04 \pm 0.10 \mathrm{~b}$ & $16.53 \pm 0.08 \mathrm{~b}$ & $\star \star$ \\
\hline F/G & $1.12 \mathrm{c}$ & $1.07 \mathrm{~d}$ & $1.25 \mathrm{a}$ & $1.07 \mathrm{~d}$ & $1.18 \mathrm{~b}$ & ${ }^{\star *}$ \\
\hline
\end{tabular}

Values are the mean \pm S.D. The means of each row followed by a different letter are significantly different. ${ }^{* \star}$ indicate $p<0.01$.

Table 3.

Mineral contents (mg/kg DM) of bee-pollen in relation to botanical origin

\begin{tabular}{ccccccc}
\hline \multirow{2}{*}{ Mineral } & \multicolumn{5}{c}{ Botanical origins } & \multirow{2}{*}{ Significance } \\
\cline { 2 - 7 } & Sunflower & Summer squash & Date palm & Rape & Alfalfa & \\
\hline $\mathrm{Na}$ & $6345.00 \pm 4.00 \mathrm{e}$ & $6525.00 \pm 2.50 \mathrm{c}$ & $6586.40 \pm 4.00 \mathrm{~d}$ & $8350.27 \pm 5.33 \mathrm{a}$ & $7311.98 \pm 5.00 \mathrm{~b}$ & $\star \star$ \\
\hline $\mathrm{K}$ & $6232.79 \pm 4.00 \mathrm{e}$ & $6416.55 \pm 4.64 \mathrm{c}$ & $6402.90 \pm 2.55 \mathrm{~d}$ & $8258.50 \pm 2.00 \mathrm{a}$ & $7214.00 \pm 1.19 \mathrm{~b}$ & $\star \star$ \\
\hline $\mathrm{Ca}$ & $2086.36 \pm 2.50 \mathrm{e}$ & $2700.73 \pm 1.43 \mathrm{~d}$ & $5629.85 \pm 2.46 \mathrm{~b}$ & $5246.94 \pm 1.50 \mathrm{c}$ & $5752.19 \pm 1.97 \mathrm{a}$ & $\star \star$ \\
\hline $\mathrm{Mg}$ & $2704.62 \pm 1.33 \mathrm{~d}$ & $2353.11 \pm 2.09 \mathrm{e}$ & $4680.53 \pm 0.76 \mathrm{a}$ & $3887.63 \pm 2.33 \mathrm{c}$ & $4557.18 \pm 1.45 \mathrm{~b}$ & $\star \star$ \\
\hline $\mathrm{P}$ & $234.40 \pm 0.88 \mathrm{e}$ & $235.30 \pm 1.10 \mathrm{~d}$ & $468.05 \pm 1.25 \mathrm{a}$ & $388.70 \pm 1.14 \mathrm{c}$ & $455.71 \pm 1.45 \mathrm{~b}$ & $\star \star$ \\
\hline $\mathrm{Fe}$ & $343.46 \pm 1.22 \mathrm{~d}$ & $562.06 \pm 4.00 \mathrm{a}$ & $338.12 \pm 1.79 \mathrm{e}$ & $361.32 \pm 1.73 \mathrm{c}$ & $533.86 \pm 1.87 \mathrm{~b}$ & $\star \star$ \\
\hline $\mathrm{Mn}$ & $18.77 \pm 0.33 \mathrm{~d}$ & $16.60 \pm 0.5 \mathrm{e}$ & $38.61 \pm 0.50 \mathrm{a}$ & $22.34 \pm 0.75 \mathrm{c}$ & $30.26 \pm 0.44 \mathrm{~b}$ & $\star \star$ \\
\hline $\mathrm{Zn}$ & $33.90 \pm 0.33 \mathrm{~cd}$ & $31.92 \pm 1.00 \mathrm{~d}$ & $40.97 \pm 0.90 \mathrm{~b}$ & $34.57 \pm 1.30 \mathrm{c}$ & $44.18 \pm 1.00 \mathrm{a}$ & $\star \star$ \\
\hline $\mathrm{Cu}$ & $6.97 \pm 0.67 \mathrm{a}$ & $6.71 \pm 0.50 \mathrm{a}$ & $4.24 \pm 0.33 \mathrm{c}$ & $6.32 \pm 0.20 \mathrm{~b}$ & $5.86 \pm 0.10 \mathrm{~b}$ & $\star \star$ \\
\hline
\end{tabular}

Values are the mean \pm S.D. The means of each row followed by a different letter are significantly different. ** indicate $p<0.01$. 
Table 4.

Pearson's correlation coefficients for minerals in bee-collected pollen

\begin{tabular}{|c|c|c|c|c|c|c|c|c|c|}
\hline & $\mathrm{Na}$ & $\mathrm{K}$ & $\mathrm{Ca}$ & $\mathrm{Mg}$ & $P$ & $\mathrm{Fe}$ & $\mathrm{Mn}$ & $\mathrm{Zn}$ & $\mathrm{Cu}$ \\
\hline \multicolumn{10}{|l|}{$\mathrm{Na}$} \\
\hline $\mathrm{K}$ & $0.99 * \star$ & & & & & & & & \\
\hline Ca & $0.60^{\star \star}$ & $0.61^{\star *}$ & & & & & & & \\
\hline $\mathrm{Mg}$ & 0.35 & 0.36 & $0.95^{\star \star}$ & & & & & & \\
\hline $\mathrm{P}$ & 0.39 & 0.40 & $0.98^{\star \star}$ & $0.99^{\star \star}$ & & & & & \\
\hline $\mathrm{Fe}$ & -0.01 & -0.01 & -0.07 & -0.27 & -014 & & & & \\
\hline$M n$ & -0.04 & -0.04 & $0.79 * \star$ & $0.90^{\star \star}$ & $0.89 \star \star$ & -0.27 & & & \\
\hline $\mathrm{Zn}$ & 0.07 & 0.08 & $0.77^{\star \star}$ & $0.87^{\star \star}$ & $0.85^{\star \star}$ & 0.09 & $0.84^{\star \star}$ & & \\
\hline Cu & 0.10 & 0.09 & 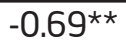 & $-0.77^{\star \star}$ & $-0.77^{\star \star}$ & 0.31 & $-0.91^{\star \star}$ & $-0.60^{\star \star}$ & \\
\hline
\end{tabular}

${ }^{* \star}$ Correlation is significant at the 0.01 level (2-tailed).

Calcium was found to have a significant $(p<0.01)$ positive correlation with $\mathrm{K}(r=0.61)$, Na $(r=0.60)$, Mg ( $r=0.95), P(r=0.98), M n(r=0.79)$, and $Z n$ $(r=0.77)$. Similarly, $M g$ had a significant $(p<0.01)$ positive correlation with $\mathrm{P}(r=0.99)$, $\mathrm{Mn}(r=0.90)$, and $\mathrm{Zn}$ ( $r=0.87)$. Also, $P$ had a significant $(p<0.01)$ positive correlation with $\mathrm{Mn}(r=0.89)$, and $\mathrm{Zn}(r=0.85)$. However, $\mathrm{Cu}$ had a significant $(p<0.01)$ negative correlation with Ca $(r=-0.69)$, $\mathrm{Mg}(r=-0.77), \mathrm{P}(r=-0.77), \mathrm{Mn}(r=-0.91)$, and $\mathrm{Zn}$ $(r=-0.60)($ Tab. 4).

\section{DISCUSSION}

Protein constitute the second most predominant group in bee-pollen, after carbohydrates. Thus, some investigators refer to the value of pollen as a source of this nutrient for human food (Orzáez Villanueva et al., 2002; Szczęsna, 2006a; b; Martins et al., 2011). Bee-pollen had from 14.71 to $19.45 \%$ DM protein. These values were significantly $(p<0.01)$ related to the plant source from which bee-pollen was collected. Protein contents could be arranged in a descending order: alfalfa > date palm > rape > summer squash > sunflower. Data published on our monoforal pollen are too poor, so we compared our data with sunflower, date palm and rape from other locations in relation to some determined components. Then we compared the ranges of components contents in bee-pollen from Al-Ahsa, Saudi Arabia with bee-pollen from other countries. The protein content of bee-collected sunflower pollen appears to be deficient and at the bottom of the range for the five major species. Data obtained in the present study confirm the findings of Somerville and Nicol (2006) in Australia, Pernal and Currie (2000) in Canada, Tasei and Aupinel (2008) in France, Nicolson and Human (2013) in South Africa who also found low protein content in bee-collected sunflower pollen. The protein level (18.14\% DM) in bee-collected rape pollen was lower than that obtained by Pernal and Currie (2000) in Canada. Here, the protein content of bee-collected date palm pollen was found to be lower than that of floral date palm pollen grains from Egypt (Hassan, 2011). This might be a result of adding nectar sugars during formation of pellets, which caused increase of the content of carbohydrates, while the protein, lipid and ash contents decreased (Nicolson and Human, 2013).

The average levels of protein found in the current study fall in the range obtained by Szczęsna (2006a) for Polish bee-pollen, Carpes et al. (2009) and Martins et al. (2011) in Brazilian bee-pollen, Tasei and Aupinel (2008) in bee pollen from France, and by Mărgăoan et al. (2012) in fresh bee-pollen from Romania. However, the average values were lower than the values found in Polish pollen by Rogala and Szymaś (2004), and by Szczęsna (2006b) in Polish bee-pollen, Chinese pollen loads, and in bee-pollen from South Korea.

The values of lipids in bee-pollen could be arranged in an ascending order: date palm < alfalfa < rape < sunflower < summer squash, with significant ( $p<0.01)$ differences among them. The high lipid levels in summer squash, and sunflower pollen were confirmed by Singh et al. (1999) for rape and sunflower, and Nicolson and Human (2013) for sunflower. The content of lipids found in our studies ranged from 1.82 to $5.38 \% \mathrm{DM}$. The average values were in the range found in Polish pollen (Rogala and Szymaś, 2004) but lower than the values obtained by Carpes et al. (2009) and Martins et al. (2011) for Brazilian bee-pollen, and by Mărgăoan et al. (2012) for Romanian fresh bee-pollen. 
The ash contents in bee-pollen could be arranged in a descending order: date palm > alfalfa > rape $>$ sunflower > summer squash, with significant $(p<0.01)$ differences among them. The low ash content in bee-collected sunflower pollen was shown by Nicolson and Human (2013). Ash content of bee pollen from Saudi Arabia ranged between 1.88 and $3.88 \% \mathrm{DM}$. This range was similar to the range in Polish pollen (Rogala and Szymaś, 2004) and in pollen from Southern Brazil (Carpes et al., 2009). In comparison to the values found in Spanish samples our values were higher than those obtained by Serra Bonvehi and Escola Jorda (1997) and by Orzáez Villanueva et al., (2002). Our results were also higher from those found in the Romanian fresh bee-pollen (Mărgăoan et al., 2012).

Fructose and glucose concentrations in the bee-pollen were significantly $(p<0.01)$ varied according to the botanical origin. Fructose content ranged between 17.13 and $21.30 \%$ DM. This range was higher than the range found in the samples from Poland, Korea, and China (Szczęsna, 2007), and the range shown for Romanian fresh bee-pollen (Mărgăoan et al., 2012). Compared with the content of fructose, the content of glucose was lower. Glucose content ranged between 15.44 and $17.06 \% \mathrm{DM}$. This range was higher than the range found in samples from Poland, Korea and China (Szczęsna, 2007), as well as in Romanian fresh bee-pollen (Mărgăoan et al., 2012). It can be noticed that the levels of glucose and fructose in the bee-pollen samples differed and considerably depended on the available honey or nectar that the bees use to form the pellets of pollen. The levels of fructose could be arranged in an ascending order: date palm > alfalfa > summer squash > sunflower > rape, while glucose: date palm > summer squash > alfalfa > rape > sunflower.

According to Mărgăoan et al. (2012), fructose to glucose index (F/G) has been related to the glycemic index in honey. In the present study, the glycemic index of bee-pollen ranged between 1.07 and 1.25. These values could be considered low compared with the values for the samples from Poland, Korea, and China (Szczęsna, 2007), and the values obtained by Martins et al. (2011) for pollen from Sergipe (Brazil). In comparison to the values of Romanian fresh pollen, the values in the present work were higher (Mărgăoan et al., 2012). The value of F/G for bee-pollen from rape (Brassicaceae) was lower than the values for Brassicaceae bee-pollen obtained by Szczęsna (2007).

We detected low levels of fibers in Saudi bee-pollen in contrast to very high level of dietary fiber detected in Spanish pollen (Serra Bonvehi and Escola Jorda, 1997). To compare, Polish pollen had $2.59 \%$ fibers (Rogala and Szymaś, 2004), and the fiber content in Brazilian pollen was between 2.20 and $4.90 \%$ (Carpes et al., 2009). Fiber contents in bee-pollen could be arranged in an ascending order: date palm < rape < alfalfa < summer squash < sunflower, with significant $(p<0.01)$ differences among them.

The high levels of protein, ash, fructose, and glucose contents found in bee-pollen from date palm and alfalfa mean that pollen from them is an excellent food supplement. Due to the high nutritional value of them, bee-pollen could be collected and stored to use as pollen supplement to feed honeybee colonies during pollen shortage periods, and as healthy and nutrient food supplement for humans.

Among the determined mineral elements in beecollected pollen, the mean levels of $\mathrm{Na}, \mathrm{K}, \mathrm{Ca}, \mathrm{Mg}, \mathrm{P}$, $\mathrm{Fe}, \mathrm{Mn}, \mathrm{Zn}$, and Cu were significantly $(p<0.01)$ varied according to the flora from which the pollen was collected. The variation in the mineral contents was mainly due to the differences in the floral origin of pollen, since the plant growth conditions, such as: soil, irrigation water, and geographic origin, and the subspecies of collector bees were the same. These ranges are similar to those obtained by Stanciu et al. (2012) for K, Mn, Zn, and Cu. Meanwhile, Na, Ca, Mg, and Fe tended to be higher than those obtained by Carpes et al. (2009) and Morgano et al. (2012). The differences among our values and the values found in other countries might be correlated to the plant growth conditions, such as: soil, irrigation water, and geographic origin. For example: the electrical conductivity of groundwater used for irrigation in Al-Ahsa oasis ranged between 1.23 and $5.05 \mathrm{dS} \mathrm{m}-1$ with $\mathrm{Na}$ as the most abundant cation. The groundwater of Al-Ahsa Oasis is mainly Na and Ca water rather than Ca and Mg dominant water (Al-Zarah, 2008).

The mineral elements in the selected bee pollen showed a predominance of $\mathrm{Na}(35.54,35.32,26.91$, 31.50 , and $28.44 \%$ of the total mineral quantified), $\mathrm{K}(34.92,34.73,26.53,31.16$, and $28.06 \%)$, Ca (11.69, 14.62, 23.33, 19.80, and $22.27 \%$ ) and Mg (15.11, 12.75, 19.39, 14.67, and $17.73 \%$ ) for sunflower, summer squash, date palm, rape, and alfalfa, respectively. According to Serra Bonvehi and Escola Jorda (1997) the predominant minerals were K, P, Ca, and Mg. Similarly, Stanciu et al. (2012) found that $\mathrm{K}$ occurred at the highest concentrations in all samples collected from Romania, followed by Ca. Similarly, $P$ was found at the highest levels followed by $\mathrm{K}$, while Ca ranked third, in pollen from Brazil (Carpes et al., 2009). 
Copper recorded the lowest percentage of all the estimated minerals in pollen from sunflower (0.039 $\%)$, summer squash $(0.036 \%)$, date palm $(0.018 \%)$, rape $(0.024 \%)$, and alfalfa $(0.023 \%)$. These results are in agreement with those of Carpes et al. (2009), and Stanciu et al. (2012).

Bee-collected pollen from date palm, and alfalfa were found to have high levels of $\mathrm{Na}, \mathrm{K}, \mathrm{Ca}, \mathrm{Mg}, \mathrm{P}$, $\mathrm{Fe}, \mathrm{Mn}$, and $\mathrm{Zn}$ which are considered to be essential for bee and human nutrition.

\section{CONCLUSION}

It was concluded that the chemical composition and mineral contents in honeybee-collected pollen can be correlated with the botanical origin. Bee-collected pollen from date palm, and alfalfa were characterised by a high content of crude protein, ash, and high levels of $\mathrm{Ca}, \mathrm{Na}, \mathrm{K}, \mathrm{Mg}, \mathrm{P}, \mathrm{Mn}$, and $\mathrm{Zn}$. Thus, it can be suggested to collect pollen loads during the blooming periods of date palm (February-March), and alfalfa (May-June) to use it as pollen supplement for feeding bee colonies during the shortage or complete absence of the pollen, or in the presence of only poor quality pollen. Also it can be used as healthy human food supplements.

\section{ACKNOWLEDGEMENT}

This work was supported by Deanship of Scientific Research of King Faisal University (Project No. 130275) in the Kingdom of Saudi Arabia.

\section{REFERENCES}

Almeida-Muradian L. B., Pamplona L. C., Coimbra S., Barth O. M. (2005) Chemical composition and botanical evaluation of dried bee pollen pellets. Journal of Food Composition and Analysis 18(1): 105-1 11.

Al-Zarah A. (2008) Chemistry of groundwater of Al-Ahsa Oasis eastern region Saudi Arabia and its predictive effects on soil properties. Pakistan Journal of Biological Science 11 (3): 332-341.

AOAC (1995) Official methods of analysis of $f$ AOAC International, 16th Edition. AOAC International. Washington, DC.

Campos M. G., Cunha A., Markham K. R. (1996) Bee-pollen. Composition, properties, and applications. In: Proceeding of the International Conference on Bee Products Properties, Applications, and Apitherapy. 26-30 May 1996: 93-100.

0.
Campos M. G. R., Bogdanov S., Almeida-Muradian L. B., Szczęsna T., Mancebo Y., Christian F." Ferreira F. (2008) Pollen composition and standardisation of analytical methods. Journal of Apicultural Research 47(2): 154161.

Carpes S. T., De Alencar S. M., Masson M. L. (2009) Chemical composition and free radical scavenging activity of Apis mellifera bee pollen from Southern Brazil. Brazilian Journal of Food Technology 12(3): 220-229.

Crailsheim K., Schneider L. H. W., Hrassnigg N., Bühlmann G., Brosch U., Gmeinbauer R., Schöffmann B. (1992) Pollen consumption and utilization in worker honeybees (Apis mellifera carnica): dependence on individual age and function. Journal of Insect Physiology 38(6): 409419.

Duncan B. D. (1955) Multiple Range and Multiple F. Test. Biometrics 11:1-42.

Folch J., Lees M., Stanley S. G. (1957) A simple method for the isolation and purification of total lipids from animal tissues. Journal of Biological Chemistry 226(1): 497-509.

Hassan H. M. (201 1) Chemical composition and nutritional value of palm pollen grains. Global Journal of Biotechnology \& Biochemistry 6(1): 1-7.

Human H., Nicolson S. W. (2006) Nutritional content of fresh, bee-collected and stored pollen of Aloe greatheadii var. davyana (Asphodelaceae). Phytochemistry 67: 1486-1492.

lannuzzi J. (1993) Pollen: food for honey bee and man. American Bee Journal 133(8): 557-563.

Kacániová M., Vuković N., Chlebo R., Haščík P., Rovná K., Cubon J., Dżugan M., Pasternakiewicz A. (2012) The antimicrobial activity of honey, bee pollen loads and beeswax from Slovakia. Archives of biological sciences 64 (3), 927-934.

Louveaux J., Maurizio A., Vorwohl G. (1978) Methods of melissopalynology. Bee World 59 (4): 139-157.

Mărgăoan R., Mărghitas L., Dezmirean D. S., Bobis O., Mihai C. M. (2012) Physical-Chemical composition of fresh bee pollen from Transylvania. Bulletin UASVM Animal Science and Biotechnologies 69(1-2): 351-355.

Martins M. C. T., Morgano M. A., Vicente E., Baggio S. R., Rodriguez-Amaya D. B. (201 1) Physicochemical composition of bee pollen from eleven Brazilian states. Journal of Apicultural Science 55(2): 107-116. 


\section{Ј. APPC. SCL. VOL. 59 N NO. 12015}

Morgano M. A., Martins M. C., Rabonato L. C., Milani R. F., Yotsuyanagi K., Odriguez-Amaya D. B. (2012) A comprehensive investigation of the mineral composition of Brazilian bee pollen: geographic and seasonal variations and contribution to human diet. Journal of the Brazilian Chemical Society 23(4):727-736.

Nicolson S. W., Human H. (2013) Chemical composition of the 'low quality' pollen of sunflower (Helianthus annuus L., Asteraceae). Apidologie 44(2): 144-152.

Orzáez Villanueva M. T., Díaz Marquina A., Bravo Serrano R., Blazquez Abellán G. (2002) The importance of bee collected pollen in the diet: a study of its composition. International Journal of Food Science and Nutrition 53(3): 217-224.

Pernal S. F." Currie R. W. (2000) Pollen quality of fresh and 1-year-old single pollen diets for worker honey bees (Apis mellifera L.). Apidologie 31: 387-409.

Rabie A. L., Wells J. D., Dent L. K. (1983) The nitrogen content of pollen protein. Journal of Apicultural Research 22(2): $119-123$.

Rogala R., Szymaś B. (2004). Nutritional value for bees of pollen substitute enriched with synthetic amino acids. Part I. Chemical methods. Journal of Apicultural Science 48(1): 19-27.

SAS Institute (2003).SAS/STAT User's Guide release 9.1. SAS Institute Inc. Cary, NC 27513.

Serra Bonvehi J., Casanova M. T. (1987) Estudio analitico para determinar la humedad del polen. Anales de bromatología 39(2): 339-349.

Serra Bonvehi J., Escola Jorda R. (1997) Nutrient composition and microbiological quality of honeybee-collected pollen in Spain. Journal of Agriculture and Food Chemistry 45: 725-732.

Singh S., Saini K., Jain K. L. (1999) Quantitative comparison of lipids in some pollens and their phagostimulatory effects in honey bees. Journal of Apicultural Research 38(1-2): 87-92.
Siuda M., Wilde J., Bąk T. (2012) The effect of various storage methods on organoleptic quality of bee pollen loads. Journal of Apicultural Science 56(1): 71-79.

Somerville D. C., Nicol H. I. (2006) Crude protein and amino acid composition of honeybee-collected pollen pellets from south-east Australia and a note on laboratory disparity. Australian Journal of Experimental Agriculture 46(1): 141-149.

Stanciu O. G., Marghitas L. A., Dezmirean D., Campos M. G. (2012) Specific distribution of minerals in selected unifloral bee pollen. Food Science and Technology Letters 3(1): 27-31.

Szczęsna T. (2006a) Protein content and amino acid composition of bee-collected pollen from selected botanical origins. Journal of Apicultural Science 50(2): 81-90.

Szczęsna T. (2006b) Protein content and amino acids composition of bee-collected pollen originating from Poland, South Korea and China. Journal of Apicultural Science 50(2): 93-101.

Szczęsna T. (2007) Study on the sugar composition of honeybee-collected pollen. Journal of Apicultural Science 51(1): 15-22.

Szczęsna T., Rybak-Chmielewska H., Chmielewski W. (2002) Sugar composition of pollen loads harvested at different periods of the beekeeping season. Journal of Apicultural Science 46(2): 107-116.

Taha E. A., Manosur H. M., Shawer M. B. (2010) The relationship between comb age and the amounts of mineral elements in honey and wax. Journal of Apicultural Research and Bee World 49(2): 202-207.

Tasei J. N., Aupinel P. (2008) Nutritive value of 15 single pollens and pollen mixes tested on larvae produced by bumblebee workers (Bombus terrestris, Hymenoptera: Apidae). Apidologie 39(4): 397-409. 